\title{
How Can Water Sector Cooperation Support Democratic Governance? Insights from Morocco
}

\author{
Annabelle Houdret \\ Senior Researcher, German Development Institute, Bonn, Germany \\ Annabelle.Houdret@die-gdi.de
}

\begin{abstract}
This paper analyzes how development cooperation can actively support democratic governance through cooperation in the water sector. To answer this question, we develop an analytical approach based on democratization research and on water governance research. We tested the approach in three donor-supported water projects in Morocco and carried out over seventy interviews with key stakeholders.

Our findings show (a) key factors influencing the scope for external support for democratic governance in the water sector, (b) potential negative effects of the support when local elites grasp new resources, and (c) unintended positive spill-over effects of water projects on democratic governance within and beyond the sector (for instance, strengthening formerly marginalized groups). As these empirical findings suggest, there is a potentially large scope of action for supporting democratic governance through water sector cooperation. We therefore highlight the need for more analytical and empirical research on causal interlinkages between these two fields of intervention.
\end{abstract}

\section{Keywords}

democratization - development cooperation - Morocco - participation - resource governance - water resources

\section{Introduction}

In a context of persisting authoritarianism in most countries of the Middle East and North Africa (MENA), development cooperation's scope of action to 
support democratic governance is limited. ${ }^{1}$ This paper examines the potential of water sector cooperation to promote participation as a key element of democratic governance and thereby bridges the polarized debate between scholars classifying political reform in the region as "authoritarian upgrading" and those identifying trends of liberalization and potentially democratization.

The role of external actors in democracy promotion has been widely discussed and some authors argue that democratic governance can be promoted through sector cooperation. ${ }^{2}$ Even in authoritarian contexts, cooperation with the regimes and their institutions could thus contribute to democracy promotion inter alia by creating spaces for participatory governance. ${ }^{3}$ However, empirical research mostly focuses on changes at the national level, one example being norm-diffusion in the context of EU accession processes. ${ }^{4}$ Less research is available on how external support can influence democratic governance at the meso-level in, or through, specific sectors. Freyburg proposes to analyze this potential through changes in "democratic governance," i.e. by not focusing on the democratization of the entire political system as such, but rather on progress in implementing democratic norms and principles, such as participation, accountability or transparency in particular political processes and institutions. ${ }^{5}$

Four main reasons explain our focus on water-sector cooperation in the predominantly authoritarian Arab world. First, the Arab uprisings in 2011 contributed to a revival of the debate on democracy promotion, and the events represent a new challenge for research but also for development cooperation and foreign policies in the region. ${ }^{6}$ The "Arab Spring" has also contributed to revitalizing the polarized debates between those scholars working on the Arab world who argue that any reform in the region is but an "authoritarian

1 The author wishes to thank Lisa Bossenbroek and Zakaria Kadiri for supporting field research for this article in Morocco and sharing their thoughts on the analysis, and Michael Roll as well as two anonymous reviewers for comments on an earlier version of this article.

2 Tina Freyburg et al., "Democracy Promotion through Functional Cooperation? The Case of the European Neighbourhood Policy." Democratization 18, no. 4 (2011): 1026-1054; Derick Brinkerhoffm, "Democratic Governance and Sectoral Policy Reform: Tracing Linkages and Exploring Synergies," World Development 28, no. 4 (2000): 6o1-615; Tulia Falleti,"Varieties of Authoritarianism: the Organization of the Military State and its Effects on Federalism in Argentina and Brazil," Studies in Comparative International Development 46 (2011): 137-162.

3 Falleti, "Varieties of Authoritarianism".

4 Tanja Börzel and Thomas Risse, "When Europeanization Meets Diffusion. Exploring New Territory," European Politics 35 no. 1(2012): 192-207.

5 Freyburg, "Democracy Promotion".

6 Ellen Lust, "Why Now? Micro Transitions and the Arab Uprisings," Monkey Cage, April 21, 2013. http://themonkeycage.org/wp-content/uploads/2011/10/Ellen_Lust_final.pdf. 
upgrading," versus those who claim that democratization or at least political liberalization can be observed. ${ }^{7}$ In this context, Freyburg's reasoning, which we have adopted for this analysis, provides a pragmatic and more specific approach; she proposes to focus on "democratic governance" rather than on democratization. Water sector cooperation provides a fruitful entry point to apply this approach since it allows for an analysis of gradual and specific changes in the sector.

Second, cooperation in, and research on, the water sector has changed from a mainly technical perspective to a more holistic understanding that includes socio-political aspects. The ample debates about, and experiences of, the role of participatory approaches (see section 2), gender aspects, ${ }^{8}$ or governance approaches at multiple levels ${ }^{9}$ are but a few examples of this transformation. Thus, there has been sustained theoretical reflection on the potential and limits of supporting governance issues in the sector.

Third, Overseas Development Assistance (ODA) in the MENA water sector is high. According to the OECD, in 2017, Germany, as the top donor to water and sanitation in the region, spent 12 percent of its total commitments in the region in this sector; commitments of Development Assistance Committee (DAC) countries for the same year were USD 17.267 million. Water sector cooperation for over 30 years in the region established trustful relationships, and large ODA commitments may thus be a conducive environment for leveraging democratic governance.

Finally, the close interlinkages between water governance and the overall governance environment may encourage spillover effects of sector support for democratic governance to the overall state - society relations. One example of these interdependencies is that authoritarian political regimes often hamper progress in water management. ${ }^{10}$ Other interlinkages include the societal

7 Paola Rivetti, "Continuity and Change before and after the Uprisings in Tunisia, Egypt and Morocco: Regime Reconfiguration and Policymaking in North Africa," British Journal of Middle Eastern Studies 42, no. 1 (2015): 1-11.

8 Margreet Zwarteveen, Effective Gender Mainstreaming in Water Management for Sustainable Livelihoods: From Guidelines to Practice (Both ENDS Working Paper Series, Amsterdam, 2006). https://www.iwmi.cgiar.org/assessment/files_new/research_projects/EffectiveGender_ BothEnds.pdf

9 Edella Sclager and William Blomquist, Embracing Watershed Politics (Boulder: University Press of Colorado, 2008).

10 Odeh Al-Jayyousi, "Reflections on Water Governance in a Changing World," Revolve Magazine (2012): 6o-73. 
discontent over insufficient and often corrupt water-service provisions that contribute to eroding regime legitimacy and fuel political contestations. ${ }^{11}$

The numerous interlinkages between the general governance context or political regime and the water sector point to a potentially fruitful environment for linking external support for the sector with targeted support for democratic governance. There is a long tradition of research on the links between water management and the deployment of state power in the MENA region, ${ }^{12}$ and some researchers explicitly address the establishment of democratic practices in water management. ${ }^{13}$ However, many of the publications specifically focusing on donor interventions in this area are limited to the local level, and rarely take into account potential 'spillover effects' on other governance levels or beyond the sector.

The present article, therefore, undertakes the endeavor of first developing elements of an analytical framework to assess the potential for reinforcing democratic governance through sector cooperation based on a review of the literature in different research fields. It then applies this framework to enquire into the interlinkages in water sector cooperation and analyzes the specific conditions of project implementation with respect to (a) general political framework conditions (such as financial and human resources and including informal aspects) and (b) specific conditions regulating access to information and participation. On the basis of this analysis, the article assesses the scope for stronger and potentially more effective external support for democratic governance in the water sector. The fieldwork was conducted in three donor-supported projects in Morocco. It consisted of a literature review, including numerous project documents and over 70 interviews with local and international project staff, project beneficiaries, local civil society

11 Luiza Toscane, "Les révolutions arabes et l'environnement: Le peuple veut de l'eau au robinet," L'Anticapitaliste 70 (2015): 12-14; Annabelle Houdret, Irene Pasqua, and Saâd Filali Meknassi, "Access to Environmental Information: A Drive of Accountable Governance in Morocco and Tunisia?" (briefing paper no. 10, Deutsches Institut für Entwicklungspolitik, Bonn, 2018).

12 To mention but a few: Karl Wittfogel, Oriental Despotism: A Comparative Study of Total Power (New York: Random House, 1957); Francesca de Châtel, "The Role of Drought and Climate Change in the Syrian Uprising: Untangling the Triggers of the Revolution," Middle Eastern Studies, 5o (2014): 521-35; Leila M. Harris and Samer Alatout, "Negotiating Hydro-Scales, Forging States: Comparison of the Upper Tigris/Euphrates and Jordan River Basins," Political Geography 29 (2010): 148-56.

13 Jeannie Sowers, "Institutional Change in Authoritarian Regimes: Water and the State in Egypt," in Comparative Environmental Politics: Theory, Practice, and Prospects, eds. Stacy Van Deveer and Paul Steinberg (Cambridge: MIT Press, 2012): 231-254. 
organizations, water-service companies, researchers, public administrations and decision-makers.

The article is structured as follows: section 2 develops the analytical framework and methods and provides a short background on the case studies. Section 3 presents the results of the empirical investigations, including three large water projects that range from drinking-water supply to irrigation and governance-support. Section 4 summarizes the key results and formulates further research needs; it also reflects on the approach adopted and formulates recommendations on how better to take advantage of the potential for democratic governance support in the water sector.

\section{Analytical Approach, Methods and Background on Case Studies}

This section develops the approach to assessing which conditions impacted the implementation of participatory approaches to water cooperation, and in this sense, may also inform the assessment of the scope for stronger support. In order to do so, it investigates relevant interlinkages between research on external support for democratic governance and research on water governance.

\section{Democratization, Democratic Governance and Sector Cooperation}

Scholars have researched the potential and limits of external support for democratization over many years; however the impact of international support remains disputed. Generally, empirical evidence on the outcomes of international democracy promotion is so far weak, as Grimm and Leininger observe. ${ }^{14}$ One can distinguish two different strands of research: the proponents of stabilization theories and those of democratization theories. The first group considers cooperation with authoritarian regimes, including through development cooperation, as regime-stabilizing. The key argument is that this cooperation strengthens the regime's output-legitimacy, as deficits in public services are compensated for by external support, but the positive outcome is attributed to public institutions and thus reinforces their acceptance..$^{15}$ The researchers argue that without this support weak output legitimacy would lead to a strong questioning of the regimes and therefore to subversive uprisings and regime change, possibly toward a more democratic regime.

\footnotetext{
14 Sonja Grimm and Julia Leininger, "Not all Good Things go Together: Conflicting Objectives in Democracy Promotion," Democratization 19, no. 3 (2012): 391-414.

15 For a literature review, see Julia Bader and Joerg Faust, "Foreign Aid, Democratization, and Autocratic Survival," International Studies Review 16, no. 4 (2014): 575-595.
} 
The other strand of research argues that cooperation with authoritarian regimes and their institutions can, by different means that include development cooperation, lead to increased support for democratization. Support for democratization at the national level is relatively well researched, and while Hinnebusch argues that "the record is patchy, at best,"16 others contend that external support can indeed contribute to a more democratic design of laws and political processes. ${ }^{17}$ The effects of external support for democratization at the meso-level are much less researched than national-level cooperation, such as within the EU neighborhood. However, there is empirical evidence that the functioning of institutions could be influenced and that, at the micro-level, changes in attitude and awareness of individuals could be observed..$^{18}$ How can we grasp these differences in the case of water sector cooperation and assess potential effects of this cooperation?

Research on water prominently addresses different governance issues, but related publications mostly focus on strengthening 'good governance' as primarily aiming at an improved functioning of policies and institutions. 'Good water governance' is in most cases not perceived to include the democratic legitimization of these sector institutions, their design and implementation, or reach beyond the sector as such. Where democratic principles such as stakeholder participation are researched, the understanding mostly focuses on "having a participatory process for the governance function on planning" as Jimenez et al. frame it. ${ }^{19}$ Research on democratization, on the contrary, generally aims at researching related evolutions of state institutions and decision-making processes, mostly at national level.

In contrast to these two approaches, Freyburg's concept of "democratic governance" assesses democratic change independently from national processes and formal progress and at different levels. This concept is "based on an understanding of democracy defined according to its underlying principles rather than specific institutions embodying them." ${ }^{20}$ Several authors argue that democratic principles can also be supported in authoritarian contexts and contribute to creating spaces for political action, participatory decision-making

16 Raymond Hinnebusch, "Globalization, Democratization, and the Arab Uprising: The International Factor in MENA's Failed Democratization.” Democratization 22, no. 2 (2015): 338 .

17 Freyburg, "The Two Sides."

18 Ibid.

19 Alejandro Jiménez et al., "Unpacking Water Governance: A Framework for Practitioners," Water 12 (2020): 827 .

20 Freyburg et al. "Democracy Promotion." 
and strengthening of democratic values. ${ }^{21}$ However, as the authors rightly mention, an increase in democratic governance does not necessarily mean progress in democratization as such. Changes in democratic governance are rather perceived as elements that may contribute to broader democratization processes..$^{22}$ In the MENA region as elsewhere, however, regimes may also support democratic practices such as participatory approaches in a context of centralized authoritarian control with the specific objective of regime stabilization. ${ }^{23}$ In Morocco for instance, arbitrary grants of licenses and resources to individual farmers or to civil society organizations has been an instrument to counterbalance the influence of political parties or social movements that are not loyal to the king. ${ }^{24}$

There is a broad literature on the promotion of democratic practices within sectors including in the water sector (see next section) but few publications engage with the potential of these approaches for spreading such practices beyond the sector. Nevertheless, some authors argue that, generally, sector reforms may have positive spillover effects to other sectors. The experiences of decision-makers or the positive impact of sector-regulation, for instance, could serve as best-practices and could be duplicated by other sectors. ${ }^{25}$ Potential spillover effects of changes in democratic sector governance to the political environment or the regime, and thus their possible contribution to democratization, are much less researched, and supposed results chains remain somewhat theoretical, since empirical evidence is weak. ${ }^{26}$

Given these limitations, it seems even more promising to look at the environmental sector for implementing external support for democratic governance. Natural resource cooperation, for instance, offers useful entry points for more sensitive topics of cooperation, including in local or transboundary

21 Jean-Paul Faguet, "Decentralization and Governance," (Economic Organisation and Public Policy Discussion Paper 27, London School of Economics and Political Science, London, 2011). http://sticerd.lse.ac.uk/dps/eopp/eopp27.pdf; Tulia G Falleti, Decentralization in Time: A Process-Tracing Approach to Federal Dynamics of Change (Oxford: Oxford University Press, 2013); Intissar Kherigi, Devolving Power after the Arab Spring: Decentralization as a Solution. (Al Sharq Forum Paper Series, Istanbul, 2017).

22 Freyburg et al. "Democracy Promotion."

23 Steven Heydemann and Reinoud Leenders, "Authoritarian Learning and Authoritarian Resilience: Regime Responses to the 'Arab Awakening', Globalizations 8, no. 5 (2011).

24 Rémy Leveau, Le fellah marocain: défenseur du trône (Paris: Presses de la Fondation nationale des sciences politiques, 1976).

25 Brinkerhoff, "Democratic Governance."

26 Ibid.; Freyburg, "Democracy Promotion." 
conflict settings. ${ }^{27}$ In the water sector, cooperation could be implemented even in highly conflictual situations, and contribute to peacebuilding in the longer term. ${ }^{28}$

The concept of "democratic governance" is a suitable lens of analysis through which to assess the scope for changes to governance principles and rules in a specific sector, and will thus serve as an analytical basis here. In order to include the relevant sector-specific factors, our analytical framework further builds on research on water governance and more specifically on insights related to participation as a key feature of democratic governance. ${ }^{29}$

The water sector has been subject to a broad range of development interventions and research on governance principles. While most of the related activities were oriented toward enabling more efficient sector governance, there are insights that the primarily "technical" implementation of governance principles, such as participation (restricted to the functioning of water-user associations, for instance), may also entail fundamental social change. ${ }^{30}$ However, the rich literature on water governance almost exclusively focuses on the sector and on the affected water user community and does seldom analyze potential effects on the broader governance environment or its democratization. Nevertheless, water governance research provides interesting insights that are summarized in the following section.

\section{Supporting Democratic Sector Governance through Participation: an Analytical Approach}

In contrast to a purely managerial understanding of water governance limited to improving the efficiency of service delivery, the notion of democratic governance expands this perspective to include the legitimacy of, and citizens' trust in, the state apparatus. As Filgueiras summarizes: "Democratic governance means administering in public and what matters, in addition to efficiency

27 Guenter Baechler, Kurt Spillman, and Mohamed Suliman, eds. Transformation of Resource Conflicts: Approaches and Instruments (Bern: Peter Lang AG/ European Academic Publishers, 2002); Tobias Ide "Does Environmental Peacemaking between States Work? Insights on Cooperative Environmental Agreements and Reconciliation in International Rivalries," Journal of Peace Research 55, no. 3 (2018): 351-65.

28 Katie Harris, Water and Conflict: Making Water Delivery Conflict-Sensitive in Uganda (Kampala: Saferworld, 2008).

29 Investigations also included research on accountability and gender-mainstreaming but these are not investigated in this article.

30 Paul Mathieu, Ahmed Benali, and Olivia Aubriot, "Dynamiques institutionnelles et conflit autour des droits d'eau dans un système d'irrigation traditionnel au Maroc," Revue Tiers Monde 42 (2001): 353-74. 
and efficacy, is the legitimacy of the state's actions, bearing in mind public policies and services capable of fostering equity and adding public value to the state's action. ${ }^{31}$ Here, the participation of the population and their integration into political decision-making is a key element of democratic governance. ${ }^{32}$ External support for participation therefore serves here as an entry point to study the conditions for its implementation and derive hypotheses and further research needs on the scope for more explicit support for democratic governance anchored in sector policies.

In water governance, participation refers to the inclusion of water users or of their representatives in the management (mobilization, allocation, distribution) of the resource at local, national or international levels. One may distinguish three stages of water-user participation: ${ }^{33}$ the lowest level is information; that is, allowing access to, and making available, information on water use, availability and distribution. This can only serve as an adequate basis for participation if the population can rely on substantial information. The second stage of participation in the water sector is consultation, whereby citizens have the opportunity to react to water-related projects. Consultation is required in many planning processes and can be oral, written or survey-based. The highest stage of participation is active involvement of the population in water policies through decision-making processes, project implementation and related monitoring activities.

Research points to many advantages of participatory approaches in water management, including the development of locally adapted solutions to water problems and more sustainable use through improved ownership. ${ }^{34}$ However, not all approaches succeed. Participatory Irrigation Management (PIM) and Irrigation Management Transfer (IMT), for instance, have, at best, shown mixed results in supporting participation. ${ }^{35}$ As their primary goal

$31 \quad$ Fernando Filgueiras, "Going Beyond Management: The Agenda of Democratic Governance and the Silenced Change in Brazil," Revista di Administracao Publica 52, no. 1 (2018): 80.

32 J. Talpin, Schools of Democracy. How Ordinary Citizens (Sometimes) Become More Competent in Participatory Budgeting Institutions (Colchester: ECPR Press, 2011).

33 Overview based on: Yorck Von Korff et al., "Designing participation processes for water management and beyond," Ecology and Society 15, no. 3 (2020): 1; Dagmar Ridder et al., Learning Together to Manage Together - Improving Participation in Water Management (Osnabrück: University of Osnabrück, Institute of Environmental Systems Research, 2005.); Matthew Hare, Rebecca A. Letcher, and Anthony Jakeman, "Participatory Modelling in Natural Resource Management: A Comparison of Four Case Studies," Integrated Assessment 4, no. 2 (2003): $62-72$.

34 Ridder et al., Learning Together; Hare et al., "Participatory Modelling."

35 Douglas L. Vermillion, Impacts of Irrigation Management Transfer: A Review of the Evidence (Research report, no. 11, International Water Management Institute, Colombo, 1997). http:// 
was to improve water management, related impact analyses do not usually analyze the broader socio-political impact. Exceptions, however, show that external support can also empower formerly marginalized groups who then raised claims for their inclusion outside the water sector. ${ }^{36}$ The creation of irrigation water-user groups has in many cases also led to broader participation of stakeholders in water management. Limits to this approach include central regimes' opposition to local democratic practices within water user institutions when realizing that these were more transparent and thus more legitimate than national elections, ${ }^{37}$ difficulties linked to implementing this in an environment with high illiteracy and powerful elites, ${ }^{38}$ or cases where formalizing previously existing unequal social hierarchies and sustaining leaders with financial resources resulted in reinforced marginalization. ${ }^{39}$

In the context of Integrated Water Resources Management (IWRM), an approach aimed at managing water at the river-basin level in a participative, cross-sectoral and sustainable way, interactions between sector governance and the broader socio-political environment are also evident and have been researched. ${ }^{40}$ Handbooks on good water governance propose a large variety of indicators and instruments to assess the success or failure in implementing participatory approaches in water management. ${ }^{41}$ Based on the literature reviewed, we can identify the following three enabling conditions as crucial for implementation and which will further guide our research:

www.iwmi.cgiar.org/Publications/IWMI_Research_Reports/PDF/pubon1/REPORT11.PDF; Peter Mollinga and Alex Bolding, eds. The Politics of Irrigation Reform: Contested Policy Formulation and Implementation in Asia, Africa, and Latin America (Burlington: Ashgate Publishing, 2004); Wafa Ghazouani, Francois Molle, and Edwin Rap, Water Users Associations in the Nen Region: Ifad Interventions and Overall Dynamics (Comombo: International Water Management Institute, 2012).

36 Mathieu et al., "Dynamiques Institutionnelles."

37 Jeannie Sowers, "Institutional Change in Authoritarian Regimes: Water and the State in Egypt," in Comparative Environmental Politics: Theory, Practice, and Prospects, eds. Stacy Van Deveer and Paul Steinberg (Cambridge: MIT Press, 2012), 231-254.

38 Ghazouani et al., Water Users Associations.

39 Brent Swallow et al., "The Challenges of Inclusive Cross-Scale Collective Action in Watersheds." Water International 31, no. 3 (2006.): 361-375.

40 Swallow et al., "The Challenges"; Kemper et al., Integrated River Basin Management.

41 Michael McGarry et al., Water Sector Governance in Africa, vol. 2 (Tunis: Water Partnership Programme of the African Development Bank, 2010); Maria Jacobson et al., User's Guide on Assessing Water Governance. (Oslo: UNDP Oslo Governance, 2013); Aziza Akhmouch and Delphine Clavreul. "Inventory of Existing Tools, Practices and Guidelines to Foster Good Governance in the Water Sector" (Paris: OECD, 2014). 
(1) The general socio-political setting, including formal political framework conditions (laws, decision-making processes, policies) and informal conditions (informal institutions including the socio-cultural setting and informal power-relations). Among these, financial resources and their independent management, human capital, as well as the presence or absence of strong elite influence or access to supportive political networks play a major role.

(2) The specific conditions regulating:

(a) Participative planning, implementation, and monitoring of water services at the project or institutional level; this includes specific legal and formal, but also informal mechanisms and processes. Findings suggest that building on existing requirements and practices may facilitate the implementation of participative approaches.

(b) Access to information as a precondition for meaningful participation; ideally enabling citizens to become informed in time and to feed suggestions into decision-making processes at different levels.

In sum, we can state that there is considerable research and practical experience on participatory approaches in water management, and participation is perceived as enabling social equality in water provision and/or management. An implicit assumption of causal relations between participation and more egalitarian social relations underpins many related publications, but most authors focus solely on the immediate sector-related environment and rarely on the wider socio-political setting. Where publications do acknowledge the importance of the broader political and institutional environment, ${ }^{42}$ they still mostly focus on improving sector governance and not on support for participation as an entry-point for change towards democratic governance. In this context, our study looks at how participation is currently implemented in water-sector cooperation in the "classical" sense, i.e. aimed at more efficient and potentially more egalitarian water governance. On the basis of these observations and related insights on the conditions for implementation, it derives hypotheses on how sector cooperation could be designed differently to contribute to more democratic governance.

\section{Methods and background on projects under study}

We have developed an analytical approach to assess the potential of water sector cooperation to supporting democratic governance. We have applied

42 Such as Implementing the OECD Principles on Water Governance: Indicator Framework and Evolving Practices (Paris: OECD, 2018). 
qualitative research methods to test this approach, given the advantages of these for seeking "to represent the complex worlds of respondents in a holistic, on-the-ground manner,"43 and understanding complex socio-ecological problems. ${ }^{44}$ We have also chosen to focus on the implementation of 'participation' as it is not only a key feature of democratic governance, ${ }^{45}$ but also an important aspect of water governance and water sector cooperation (see section 2.2).

We have used a case study approach based on three donor-supported projects in the water sector in Morocco. We selected these three projects from a broad variety of potential donor-supported activities in the section because of four reasons. First, we opted for three projects addressing different target groups ranging from local farmers to high-level policy-makers to represent a broad range of potential addressees and various political settings. Second, we chose the projects according to their areas of intervention and minimum project duration. The three cooperation activities represent typical domains of water sector cooperation (drinking water supply, irrigation water supply, and integrated water resources management), and at the time of the interviews all projects had been supported for at least five years and could thus provide insights on variables potentially impacting the implementation of participatory approaches. Third, we opted for three projects implemented in the Souss region (with one of the projects additionally carrying out activities at the national level) in order to have a similar sociocultural and environmental setting. Fourth, all of the projects under analysis needed to include at least some components dealing with participation. Unlike specific donor projects dedicated to strengthening democratic governance as such, the projects under investigation here only had limited components dealing with governance issues. Nevertheless, all projects did have activities related to stakeholder participation and were thus an appropriate entry point for a study of its implementation.

We conducted the empirical studies with an interdisciplinary research team involving the author and two local researchers. In a first round, the team investigated socio-economic, political and technical aspects of participatory water management in the three project areas and conducted twenty interviews with representatives of farmers, drinking water associations, local and national

\footnotetext{
43 Deborah Padgett, Qualitative Methods in Social Work Research (Thousand Oaks: Sage Publication, 2017).

44 Niki A. Rust et al., "Quantity Does Not Always Mean Quality: The Importance of Qualitative Social Science in Conservation Research," Society \& Natural Resources, 30, no. 10 (2017): 1304-1310.

45 Talpin, Schools of Democracy.
} 
water and agriculture administrations, donors and their local consultants, and local researchers. This phase also served to collect more information on the projects and respective policies (planning, implementation and evaluation reports, respective laws and decrees, and other public policy documents), and to test the guidelines for the qualitative interviews. A second round of field visits was conducted in the three project areas and in Rabat to conduct fifty-two semi-structured interviews with relevant stakeholders (twenty female and thirty-two male). These interviews were conducted with eleven local and six national-level representatives of water and agriculture administrations, eighteen villagers involved in drinking or irrigation water projects, six consultants implementing the projects on behalf of donor agencies, five representatives from the donor agencies supporting the three projects under study, three representatives of a drinking water association, and three representatives of an irrigation water association. Rather than aiming for a representative quantitative sample of all stakeholders, we wanted to explore in qualitative depth how implementing agencies, their partner administrations, and local target groups of the projects experienced the implementation of participatory approaches, and how this impacted their further activities within and beyond the water sector. Interview data, including the results of the focus group meetings with drinking and irrigation water associations, were analyzed using qualitative approaches. The preliminary results were discussed with researchers from the region and selected representatives of development cooperation and local stakeholders.

The three projects selected for our empirical research are all located in Southern Morocco's Souss region, in a mostly rural area characterized by high water scarcity, lucrative but water-intensive irrigated agricultural projects, and a large share of smallholders. The first project (1) focused on improving the rural drinking-water supply by creating local user associations. This project included water mobilization through drilling or wells, building supply infrastructure with pumps, tubes and water-storage facilities, and capacity building for the related technical and managerial skills of the user groups. The second project (2) aimed at improving small- and medium-sized irrigation schemes to contribute to higher agricultural income and to improve irrigation water savings. Development cooperation together with local administrations implemented both projects over ten years. Both projects are rather technical, involving only a few activities related to governance (such as participatory approaches in water management). We chose these projects as they represent the majority of donor-financed water projects in the region and entails a potentially large scope for action due to the important sums of related loans or, less frequently, grants. The goal of the third project (3) under investigation was to improve the 
governance and management capacities of the Moroccan water sector to foster an integrated, sustainable and socially equitable management of the resource. It consisted of a large array of activities ranging from the local (water basin) level to the national level.

All three projects had explicit components addressing participation. The irrigation and drinking-water projects ( 1 and 2 ) focused on participation at the local level, where they supported the creation of water-user groups for planning and managing water services: Association d'Usagers de l'Eau Agricole (AUEA) in the irrigation sector, and Association d'Usagers de l'Eau Potable (AUEP) in the drinking-water sector. The creation of user groups was mandatory for the project implementation according to Moroccan water law. These user groups underwent several measures for administrative, financial, and technical capacity development. All groups elect representatives, such as a president, a treasurer etc., take part in regular meetings of the association, and are responsible for the technical maintenance of the water infrastructure. Project 2 (irrigation) also aimed to reinforce participatory governance within relevant local agricultural institutions.

Project 3 explicitly addressed participation as an important element supporting the implementation of IWRM. While the project addressed governance deficits in the sector, it mostly focused on organizational and management issues. It contributed to strengthening participation in national-level processes and at the local level of river basins. It also implemented participatory approaches in its work with local institutions, for example when developing a system for measuring the performance of employees of a river-basin agency.

\section{The Scope for Action: Empirical Evidence from Water-Sector Cooperation in Morocco}

This section presents the results of our empirical investigations into the interlinkages between water-sector cooperation and support for participation as a key element of democratic governance. Field research also revealed several interesting instances of spillover effects of external support with an indirect impact on democratic governance. Such effects happened with respect to water governance but were beyond the geographical scope and target-group of projects, and also beyond the water sector as such.

\section{Enabling Conditions and Limits of External Support}

Empirical evidence shows that political framework conditions as defined in section 2 influenced the implementation of water cooperation projects, both 
as a factor of success and as a potential limit of their leeway. Informal rules and power relations proved to influence this in all fields and at all levels of intervention.

The political framework conditions can strongly influence the enabling environment for the implementation of participatory approaches in all projects, especially when it comes to replicating or upgrading experiences in different settings or to involving new stakeholders. As the following examples illustrate, formal policies and institutions, but also informal relations, can positively or negatively impact external support. This confirms earlier findings on water governance in Morocco that highlight how the local appropriation of international strategies and funding is used by specific interest groups for sustaining power relations and securing private benefits. ${ }^{46}$

When it comes to the regulations on participation, legal and other formal or informal mechanisms play a significant role. Positive experiences include cases where mechanisms for participative planning and implementation of water services were already at least formally anchored in the political framework (i.e. in the water law), and donor support could then assist in implementing this. For example, interviewees positively reported on donor support for decentralized water-basin agencies and the participative approach used in many activities of project 3 . This illustrates that development cooperation can activate existing formal requirements for democratic practices and thereby deepen them and contribute to strengthen their appropriation by the local community and institutions, including public administrations. As this study only focused on the Moroccan context where these requirements were at least formally put in place, no case of donor activities that could not rely on this support could be analyzed.

At the same time, field research revealed that the mere existence of legal and formal mechanisms for participation is sometimes not enough to ensure efficient implementation. In projects 1 and 2, which supported the creation of associations for users of drinking/irrigation water, the donor-financed technical assistance (тА) consisted of conducting the initial training of the groups and providing temporary support for technical and management issues. After this period, the local administrations were supposed to coach the user groups

46 Oumaima Tanouti and François Molle. "Réappropriations de l'eau dans les bassins versants surexploités," Études Rurales 192 (2013): 79-96; Kevin Del Vecchio and Sylvain Barone. "Has Morocco's Groundwater Policy Changed? Lessons from the Institutional Approach," Water Alternatives 11, no. 3(2018): 638-662; Rhoda Fofack, Marcel Kuper, and Olivier Petit, "Hybridization of Rules for Access to Groundwater in the Saïss (Morocco): Between Anarchy and Leviathan?" Études Rurales 196, no. 2 (2015): 127-150. 
further. However, in spite of the institutions' commitment, they were not able to support the groups in an adequate way due to their own lack of resources. At the agricultural administration, a single employee was responsible for coaching 142 irrigation-user groups spread over a large territory and was supposed to participate in all their meetings and advise them. The situation of the drinking-water administration was similar: only 2 employees were responsible for monitoring the project's 96 drinking-water-user groups in addition to many other groups outside the project area. Both institutions chronically suffer from a lack of staff and from underfunded budgets; evaluation reports further reveal a shortcoming in the monitoring of drinking-water quality and a lack of awareness about wastewater management. At the end of the TA contract period, a vacuum often arose, leading to major difficulties, including the de facto dissolution of user groups. The goal of the participatory approach - to enable users to operate their facilities independently - was thus threatened, and investment in infrastructure may have been jeopardized.

Political framework conditions can, however, also limit the scope of donor support for participation. Project 3 (on IWRM) learnt from its own experiences when it successfully conducted several participatory planning activities in a river basin, but it could then not gain enough political support at higher level for the implementation of the measures agreed. As in other cases in the MENA region, ${ }^{47}$ participation among local stakeholders had been initially successful, but this participation failed to mobilize at higher levels of decision-making. In contrast, new project activities in another river basin which had first ensured the support of the highest regional political authority, the "Wali" (representing the Ministry of Interior at the regional level), managed to be much more effective, including in implementing participation. ${ }^{48}$

Project 3 also supported different sectoral administrations in an inter-ministerial steering committee for the development of a program for rural wastewater treatment. While cross-sectoral coordination for water management is known to be highly political and often very difficult to implement, ${ }^{49}$ project 3 at least managed to get the actors around the same

47 Eglal Rached and David B. Brooks, "Water Governance in the Middle East and North Africa: An Unfinished Agenda," International Journal of Water Resources Development 26, no. 2 (2010): 141-155.

48 Interviews with a representative of a water basin agency, a representative of development cooperation, and a consultant working with development cooperation.

49 Subramanian Saravanan, Geoffrey T. McDonald, and Peter Mollinga, "Critical Review of Integrated Water Resources Management: Moving Beyond Polarised Discourse," Natural Resources Forum 33, no. 1 (2009): 76-86. 
table, and the donor supported the development of a new legal framework for water reuse. Nevertheless, the Ministry of Agriculture then blocked the initiative; the political framework conditions - with the respective Minister being a highly influential person - interfered with and hindered the implementation of the outcome of the participatory approach for some time. ${ }^{50}$

A third example illustrates how informal political framework conditions also impact the donors' scope for action. A donor-supported initiative for a participatory design of an aquifer contract was launched to manage groundwater in a sustainable way (project 3 ). The context was both environmentally and politically sensitive, as it was characterized by high water scarcity and water overexploitation, combined with a lucrative cash-crop cultivation by often highly influential political elites. Only some of the small farmers, who would benefit from more sustainable resource use in the longer term, ${ }^{51}$ were part of the initiative, but richer farmers dominated the process. However, this initiative only led to a very limited involvement of water users in water-conservation measures and in financing, and the agreed control of illegal water abstraction did not materialize in a satisfactory way. Stakeholders had agreed, in a participatory way, on certain targets and measures but did not agree on sanction mechanisms, nor did they always have the necessary resources and political backing to implement related measures (for example, having the local administration control water use). This experience largely echoes previous findings on the limits of participatory approaches in a setting characterized by strong elite influence; it is necessary for strong highlevel political support to back the outcome of the participatory process. ${ }^{52}$ Pahl-Wostl rightly summarizes the transformative potential of water governance: "Political will is also needed and often lacking."53

In addition to the general political setting, the specific socio-cultural environment also played a significant role. The Souss region is known within Morocco for its commitment to, and solidarity of its Berber population. Their

$5^{\circ}$ Interview with a representative of development cooperation.

$5^{1}$ They mostly cannot afford to dig deep in order to reach the ever-sinking aquifer and also have difficulties in obtaining the permit to do so, see Annabelle Houdret, "The Water Connection: Irrigation, Water Grabbing and Politics In Southern Morocco," Water Alternatives 5, no. 2 (2012): 284-303; Nicolas Faysse et al., "Formulation and Implementation of Policies to Deal with Groundwater Overuse in Morocco: Which Supporting Coalitions?" Irrigation \& Drainage 61 (2012): 126-134.

52 Rached et al., "Water Governance"; Ghazouani et al., "Water Users Associations."

53 Claudia Pahl-Wostl, "An Evolutionary Perspective on Water Governance: From Understanding to Transformation," Water Resource Management 31 (2017): 2917-2932. 
tradition of Twiza is an institutionalized mutual-help system within the village community. Support of participative water governance was thus implemented in a very fruitful setting and could build upon existing social ties. Similar observations in other regions confirm that previously established collective action, as long as it was not coercive, was an enabling factor of new collaboration processes. $^{54}$

However, the sociocultural context and its power relations can also severely limit the scope for participatory approaches, for instance in settings with socioeconomically non-homogeneous populations. In contrast, similar user interests, comparable socialization and educational background (general education but also common knowledge on farming techniques for instance), as well as pre-existing contacts in many cases favored dynamic and efficient user associations. ${ }^{55}$ In one case of a donor-supported irrigation project, local elites usurped participative approaches and structures. Two families of large landowners who have traditional water rights and sell water lucratively to downstream residents were - as other farmers - involved in the participatory planning but then blocked the project implementation for years. The project envisaged a replacement of surface-water irrigation by a pressurized system, thus literally drying up the source of income for the large landowners. Interestingly, the technical innovation of pressurized irrigation schemes theoretically opens up the possibility of overcoming existing social and economic inequalities by allowing the previously marginalized downstream farmers to use the irrigation supply under the same conditions as the privileged upstream farmers. In practice, however "development cooperation cannot ignore these established power relations, which is why we have negotiated with the large landowners," as one interviewee from a development cooperation agency involved in the implementation stated; representatives of local administrations involved articulated similar remarks. The landowners were offered various forms of compensation, but no agreement had been reached at the time of the surveys. This corroborates the findings on the influence of political-framework conditions, as only a high-level intervention from political decision-makers could have forced the large farmers to accept the new irrigation system.

54 Marcel Kuper et al.,"Supporting the Shift From State Water to Community Water: Lessons from a Social Learning Approach to Designing Joint Irrigation Projects in Morocco," Ecology and Society 14, no. 1 (2019): 19.

55 Kadiri, Zakaria. "Laction publique à l'épreuve de la participation: Généalogie du projet d'irrigation du Moyen Sebou au Maroc," (dissertation, Ecole Doctorale Espaces, Cultures, Sociétés, 2012). 
Many interviewees perceived the availability of, and access to, information as a crucial aspect for their participation in water-user organizations. They referred to the citizens' strong commitment to raising their own financial contribution for the water-user groups, ${ }^{56}$ despite the low incomes in rural areas, as a proof of their trust in the project that had previously been introduced by careful explanation and information. ${ }^{57}$ Availability and access to information were also at the center of power struggles over the implementation of aquifer contracts. One donor explicitly aimed at improving the availability of information on the degradation of water and land use in order to strengthen shared knowledge about the alarming situation. ${ }^{58}$ The considerable effort made to obtain this information was aimed at strengthening the ownership of measures to protect the resource and especially the newly created aquifer contract..$^{59}$ However, this information on water and land use was of high political sensitivity, as influential individuals were responsible for a large share of water overuse, often in sharp contrast to official regulations. ${ }^{60}$ Subsequently, in spite of the large amount of information available, diffusion of, and access to, this material was severely restricted and could therefore not be used as previously planned. Generally, when development projects aimed to improve access to information for citizens, they were successful regarding information related to the project design and implementation, but less so when it came to higher political levels and/or non-water-related issues; the target group could feed suggestions into the project implementation, but much less so into other decision-making processes.

\section{Observed Spill-Over Effects}

Spillover effects of external support for participation observed during field research took different forms: first, support for participatory approaches contributed to empowering individuals or groups who subsequently built new alliances and played a stronger role at higher (but still local) levels within the water sector. Second, individuals or groups used the skills acquired during

$5^{6}$ Both user groups raise membership fees, which are collected for the initial investment ( $5 \%$ own contribution for the drinking water projects and between $2.5 \%$ and $10 \%$ for the irrigation projects), for the maintenance of the infrastructure and for a fund for pending repairs.

57 Interviews with 2 presidents and 2 members of drinking water associations, and with a consultant working with development cooperation in project implementation.

$5^{8}$ Interview with a representative of development cooperation.

59 Interviews with a representative of development cooperation and a representative of the local water basin authority.

6o See also Faysse et al, "Formulation and Implementation." 
training for participation to initiate new activities beyond the water sector (such as income generation or local development projects). This is, of course, not per se a spill-over effect with respect to democratic governance, but it shows that external support can help empower formerly marginalized groups, who can then play a different role in their socioeconomic environment and contribute to altering governance modes. ${ }^{61}$

Interestingly, such strengthening of the autonomy of local user groups was not seen as threatening, but rather as promising new forms of governance, by many representatives of local administrations. Interviewees from local water and agriculture administrations reported their satisfaction with having competent and reliable partners for local water allocation, and expressed their trust in existing groups, whom they often perceived as not only being in charge of water management but also of local development and social mobilization for new development initiatives. This may be even more surprising as the projects did not, in most cases, explicitly aim at changing the relations between citizens and administrations. Approaches that explicitly include the institutional environment, i.e. decision-making processes beyond the local level and beyond the water sector, can thus be a fruitful entry-point to harness the donor's scope for supporting democratic governance.

The unexpected creation of a federation of water-user groups is one example illustrating these findings. Following the successful training of drinking-water user organizations (AUEP), some of these expressed the wish to establish an association of user organizations. The meetings of the AUEP presidents within the project activities had helped to strengthen exchange on common problems. The main motivation for the creation of a federation was to gain more power vis-à-vis the drinking-water provider and private companies, and to institutionalize mutual exchange beyond the duration of the donor support. Although this was not originally planned, the donor was able to back the 74 groups in setting up the federation. According to several participants, the approval was initially on the brink of collapse in 2012 because of the sensitive political context during the "Arab Spring." The federation was considered to be potentially disturbing, possibly mobilizing people to claim improved access to drinking water and thereby contributing to social upheaval. ${ }^{62}$ After several months, the foundation of the federation was finally approved at provincial level. Today,

61 See also Fernando Filgueiras, "Going Beyond Management: The Agenda of Democratic Governance and the Silenced Change In Brazil," Revista di Administracao Publica 52, no. 1 (2018): 71-88.

62 Interviews with a representative of development cooperation, a representative of the local agricultural authority, and a president of a water user association. 
the federation promotes the exchange of knowledge between its members, acts as an intermediary vis-à-vis ONEE, and has negotiated a framework agreement with a local company that includes favorable conditions for the maintenance of the water networks. The example shows that capacity building in the context of support for participation - including the group-building process, technical issues, and project management and accounting - has considerably strengthened the ability of some groups to self-organize. While local sector administrations apparently appreciated their new technical and managerial capacities, representatives of the Ministry of Interior (responsible for the authorization of the federation) were reportedly more skeptical. This may also indicate that, in spite of their anchoring in the water sector, such federations have a potential impact that reaches beyond the sector and is conceived of as a potential force of social mobilization. This would second what Filgueiras sees as a contribution to a democratization process where "new forms of citizen empowerment are directed and orientated by the constitution of changes in public administration." ${ }^{63}$ However, as Sowers rightly points out in light of her findings in Egypt, the impact of such external support remains limited as long as the "inner circle of the political elite in the Cabinet and the mid- and lower-levels employees of the Ministry"64 are not part of the process. Given the insights of our case studies, we would add other concerned administrations at all levels, but first and foremost, the Ministry of Interior (which, in Morocco, remains one of the three Ministries operating under the auspices of King Mohamed vi). ${ }^{65}$

Other statements by representatives of public administrations, water users themselves, and local inhabitants confirm that the experiences and skills acquired by the externally supported participation mechanisms often empowered formerly marginalized individuals and groups. Young and partly well-educated adults from the villages, for instance, were often involved in the creation of, and training for, water-user organizations. The new skills subsequently not only enabled them to initiate further development projects, but also allowed them to play a more active and visible role in local

63 Ibid.

64 Sowers, "Institutional Change."

65 This, in turn, seconds earlier findings on the limited authority of local administrations and all elected bodies in Morocco even after the latest decentralisation reform and the persistence of centralized decision-making under monarchic rule. Annabelle Houdret and Astrid Harnisch,. "Decentralisation in Morocco: A Solution to the 'Arab Spring'?" The Journal of North African Studies 24, no. 6 (2019): 935-96o. 
decision-making, a process often dominated by elderly men. ${ }^{66}$ This also applies to some women's groups who, for instance, mobilized the financial contribution needed for the villages' participation in drinking-water projects by weaving and selling carpets. Beyond the successful mobilization of money for the water projects, this also helped them realize their own powerful capacities and, in some cases, led to further mobilization for local development projects. However, the donor-supported training for the creation of user associations primarily focused on men; they were thus the ones who benefitted most, in the longer term, from capacity building, while related training for women was mostly limited to water and hygiene measures. Even given the (in some respects) challenging cultural environment in rural Morocco, this can clearly be seen as a missed opportunity for supporting democratic governance in and through a water project.

The successful mobilization of user groups, and the (sometimes considerable) revenue surpluses of associations have, according to the respondents, strengthened the confidence of both the inhabitants and state institutions in the ability of local self-governance. This has helped to mobilize public funds for new development projects and also shows interesting pathways beyond the usual top-down governance structures. Several AUEP have used their revenues and their new management capacities to initiate further development projects for their village, such as the purchase of an ambulance or a school bus, literacy courses, or the fortification of paths. As a result, after four to five years, the AUEP or individuals involved became independent local development actors in addition to their role in the water sector. This can lead to changes in local governance. In some cases, however, the newly created financial flows also led to accountability problems, for instance when a lack of external control allowed for corruption or the stealing of collected funds.

As several examples showed, new forms of autonomy and cooperation with sector institutions can be in the interest of both the population (who are able to design and implement projects corresponding to their needs) and state institutions (who are often willing but due to limited capacities unable to assist them in doing so). Representatives from local administrations stated that their experiences with the delegation of responsibility to user groups were largely positive and contributed to helping their chronically overburdened institution. The positive impact of this in terms of trust in and legitimacy of the associations as a new local player can be an important unintended side effect impacting local

66 Interviews with a representative of the local agricultural authority, a consultant working in a development cooperation project, and a member of a water user association. 
governance. In addition, these actors can often be complementary, as an interviewee from the public administration for agriculture stated: "We are here for the technical issues, but we need the associations for the social issues." While more general findings on participatory approaches in Morocco including in development projects highlight severe limitations to such approaches due to persisting centralized state control, ${ }^{67}$ our findings suggest that, until reaching a certain 'red line,' meaningful cooperation between public administrations and local civil society groups can play out positively when being in all parties' interest and not, as other findings also suggest, challenge the internal legitimacy of local decision-makers. ${ }^{68}$ Better understanding the nature and limits of these 'red lines' in different sectoral, political and regional contexts within the country and beyond should therefore be at the center of future research on external support to democratic practices in sector cooperation.

\section{Conclusion}

This paper analyzed the external support for participation in water-sector cooperation in order to assess the conditions for implementation and to provide hypotheses concerning the scope of more explicit support for democratic governance in the sector. The analysis confirms earlier findings on the influence of formal and informal factors on the scope for supporting participation and shows how this plays out in practice. Moreover, it reveals that support has led to unintended effects, with a potential positive impact on democratic governance within and beyond the sector. These findings suggest that there is considerable scope for stronger, more targeted, and more explicit support for democratic governance in and through the sector, including in predominantly technical projects and in authoritarian contexts. This potential so far remains underexploited for two reasons: first, donor organizations have not explicitly articulated the will to support democratic governance in sector cooperation. Second, practical and scientific knowledge on conceptual and empirical interlinkages between sector cooperation and the promotion of democratic governance across different levels in authoritarian contexts are, so far, weak. Therefore, the related causal mechanisms and impacts of external

67 Sylvia Bergh, The Politics of Development in Morocco: Local Governance and Participation in North Africa (London: I.B. Tauris, 2017).

68 Beata Paragi, "Divide et Impera? Foreign Aid Interventions in the Middle East and North Africa Region," Journal of Intervention and Statebuilding 10, no. 2 (2016): 200-221. 
interventions on people, structures, and institutions beyond the water sector need to be studied more in detail.

The framework of analysis used here, a combination of approaches from research on democratization and on water governance, proved useful for understanding the conditions of implementation of external support for participation, which are likely to affect support for other elements of democratic governance in the sector too.

Several factors determined the scope of action for external support. The political context proved to be highly influential at different levels (including factors such as legal frameworks and formal mechanisms, the existence of qualified and sufficient human resources and of financial support, and the availability of and access to information). At all levels of intervention, besides formal conditions, socio-cultural factors and the interests determined by the specific political economy of actors and institutions, played a major role in the implementation. These factors played a very positive role in some cases where existing solidarity mechanisms, group homogeneity, and common interests provided a fertile ground for external support of participatory approaches. However, they also limited the impact of external support, for instance when user suggestions could not be fed into formal decision-making processes and to higher levels of decision-making, or where power struggles between individuals or institutions limited the scope of action. In some cases, the political economy even negatively influenced external interventions, for instance when captured by local elites.

Empirical research also revealed potential spillover effects of targeted support for participatory governance in the water sector. It needs to be emphasized that none of the projects explicitly aimed at reinforcing democratic governance beyond the sector and that the effects observed were thus unintended. For this reason, any more precise and reliable insights into causal relations would require more in-depth research, ideally in a context where the intervention explicitly aimed at influencing governance beyond the target group and/or beyond the sector. However, our investigations clearly showed that support for participatory governance in the water sector, in some cases, could empower other formerly marginalized groups. Related capacity building contributed not only to developing technical and managerial skills that were then used to implement other local development projects, it also strengthened the groups' ability to self-govern and improved their self-confidence. This contributed to innovative approaches, such as the creation of a federation of water-user associations, and also had a positive impact at the institutional level. Interviewees in local administrations, for example, welcomed these new skills and were relieved to have stronger partners for local development in the 
context of a lack of resources in their own institutions. Positive experiences with participation thus contributed to strengthening local autonomy and establishing or legitimizing new forms of governance - an insight that seems particularly interesting in the search for new ways to externally support democratic governance. However, several experiences also pointed to the need for higher-level political support whenever such practices or resulting larger interest groups were perceived to gain larger influence.

Summarizing the results on external support for participation in the water sector, it can contribute to strengthening the commitment, ownership and capacities of partner institutions in the water sector and beyond, and can be a productive trigger of innovative experiences with new forms of governance. However, the success of such support often depends on political support beyond the water sector, benefits from formal regulations and the availability of and access to information. It also needs to be adapted to the sometimes very specific political economy of local institutional or actor constellations, which can positively or negatively affect external support. Moreover, as in any development intervention, the principle of "do-no-harm" 69 needs to be carefully considered, as external interventions may have harsh unintended effects.

Overall, insights gained from the theoretical reflections and the empirical investigations suggest that water-sector cooperation can contribute to more democratic governance, even if (or perhaps in some cases of harsh authoritarian control, only if) implemented 'indirectly.' Given the difficulties of openly promoting support to democratic governance in the region, indirect support through strong governance components in primarily technical sector cooperation may be a more promising avenue for donors. The sector seems an especially useful entry point if development cooperation identifies specific windows of opportunity and provides targeted and longer-term support for such activities. Supporting participation may have more far-reaching and sometimes unintended impacts than originally conceived of in a project. If donors aim to have any effect on democratic governance in and through the water sector, assumptions have, at least internally, to be made more explicit and activities need to be backed by better knowledge on causal mechanisms. Based on this, the approaches to planning, monitoring, implementing and evaluating project interventions in the water sector in order to better support democratic governance need to be adapted. New projects in this sense should have strong governance components that are closely linked to technical interventions, but also to other external interventions. This can also enable better

69 Mary B. Anderson and Marshall Wallace, Do No Harm: How Aid Can Support Peace - or War (Boulder: Lynne Rienner Publishers, 1999). 
coordination within and between donor agencies when, for example, a territorial approach is adopted and democratic governance is backed up in different sectors, administrations and target groups of the same region.

For the research community, this study clearly points to the need for new avenues of thinking on how to combine predominantly technical sector cooperation and support for democratic governance. As findings from this paper and those of other authors suggest, the potential scope for action to make better use of existing interlinkages is large. However, in order to better grasp this potential both analytically and practically, more research is needed on (a) the interlinkages between sector cooperation and democratic governance at different levels and in different sectors and settings (such as diverse cultural and political environments), (b) causal mechanisms (the interdependencies between sector governance and the overall governance/regime-context), and the impact of external interventions on these, and, ultimately, (c) potential unintended effects of external intervention in this field that may be contrary to their original goal (such as the marginalization of certain groups or political destabilization). 